\title{
Acute and 28-Day Repeated Inhalation Toxicity Study of Glycolic Acid in Male Sprague-Dawley Rats
}

\author{
SEONG KWANG LIM ${ }^{1}$, JEAN YOO $^{1}$, HAEWON KIM $^{1}$, WOONG KIM ${ }^{1}$, ILSEOB SHIM ${ }^{1}$, \\ BYUNG-IL YOON $^{2}$, PILJE KIM ${ }^{1}$, SEUNG DO YU ${ }^{1}$ and IG-CHUN EOM ${ }^{1}$ \\ ${ }^{1}$ Environmental Health Research Department, \\ National Institute of Environmental Research, Incheon, Republic of Korea; \\ ${ }^{2}$ College of Veterinary Medicine and Institute of Veterinary Science, \\ Kangwon National University, Chuncheon, Republic of Korea
}

\begin{abstract}
Background/Aim: The use of glycolic acid is present in a variety of consumer products, including medicines, cleaners, cosmetics, and paint strippers. It has recently led to concerns about toxicity from inhalation exposure. Herein, the pulmonary toxicity of glycolic acid was investigated in rats. Materials and Methods: We conducted acute $\left(\sim 458 \mathrm{mg} / \mathrm{m}^{3}\right)$ and sub-acute $\left(\sim 49.5 \mathrm{mg} / \mathrm{m}^{3}\right)$ inhalation tests to identify the potential toxicities of glycolic acid. Results: Inhalation exposure to glycolic acid in the acute and subacute inhalation tests did not cause any specific changes in clinical examinations, including body weight, organ weight, hematology, serum biochemistry, and histopathology. The polymorphonuclear neutrophils (PMNs) and inflammatory cytokines in Bronchoalveolar lavage fluid $(B A L F)$ increased in rats exposed to single and repeated inhalations. In the sub-acute test, the changes induced by glycolic acid were minor or returned to normal during the recovery period. Conclusion: The No Observed Adverse Effect Concentration (NOAEC) for the nasal and pulmonary toxicity of glycolic acid was determined to be over $50 \mathrm{mg} / \mathrm{m}^{3}$ at the end of a 28-day inhalation test in male rats.
\end{abstract}

Many chemicals are used in consumer products, such as cosmetics, toys, paints, and cleaners; consequently, consumers are exposed to these chemicals through the oral route, the skin, and by inhalation (1). However, the

This article is freely accessible online.

Correspondence to: Ig-Chun Eom, Environmental Health Research Department, National Institute of Environmental Research, Incheon 404- 708, Republic of Korea. Tel: +82 0325607169, Fax: +82 0325682037,e-mail: iceom@korea.kr

Key Words: Acute, glycolic acid, inhalation exposure, subacute, toxicity. inhalation toxicity of these compounds has not been well studied compared to other tests that may cause oral toxicity (2). Glycolic acid (also called hydroxyacetic acid) is an alpha hydroxyl acid (AHA) naturally present in food, such as sugar cane and fruits $(3,4)$. Glycolic acid is also used in household products, such as chemical peels, household cleaners, textile finishing solutions, and paint strippers $(5,6)$.

Glycolic acid is not mutagenic and has not been classified as responsible for development of cancer $(6,7)$. Oxalateinduced renal calculi have been found in a short-term study of glycolic acid and oxalate has been found to increase nephrotoxic effects in a chronic study $(8,9)$. The FDA has approved the use of glycolic acid as an indirect food additive (10). A cosmetic ingredient review (CIR) has concluded that glycolic acid is safe for use in cosmetics at concentrations below $10 \%$ and at final formulation above $\mathrm{pH} 3.5$ (10). The National Industrial Chemicals Notification and Assessment Scheme (NICNAS) have indicated that products containing $20 \%$ glycolic acid or less, at $\mathrm{pH} 3.5$ or above, are not expected to cause skin irritation (6).

Glycolic acid is a major metabolite of ethylene glycol (11). Ethylene glycol is used in consumer products, such as antifreeze, brake fluids, and inks, to which consumers are exposed through oral, inhalation, or dermal routes (12), and is not considered a carcinogen $(13,14)$. However, many studies have reported that high-dose exposure to ethylene glycol causes nervous system depression, metabolic changes, cardiopulmonary symptoms, nephrotoxicity, hepatotoxicity and developmental toxicities (15-19). Glycolic acid is metabolized to oxalate, glycine, and formate by glycolic acid oxidase or lactic dehydrogenase (20-23). These metabolites can be broken down into carbon dioxide and other metabolites, which are exhaled or excreted through urine (24-26). Oxalate, a metabolite of glycolic acid, may also be excreted in urine, but can also produce calcium oxalate crystals (27).

There are currently many spray-type products on the market that contain, glycolic acid (28). As the probability of 
$\mathbf{A}$

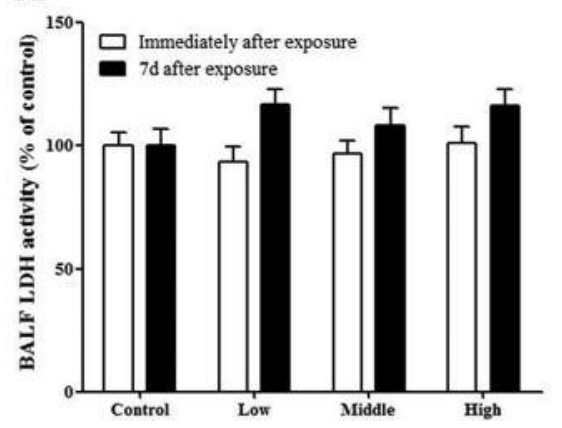

B

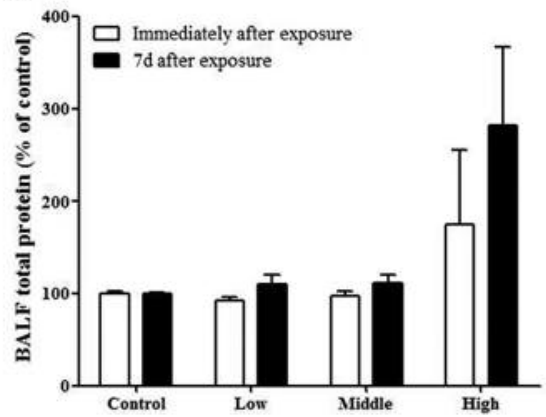

C

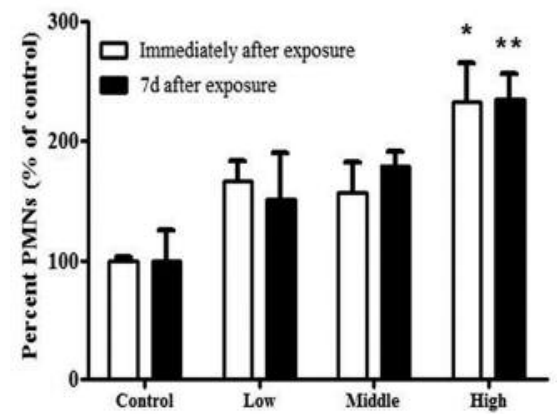

Figure 1. The pulmonary toxicities induced by the acute inhalation test of glycolic acid in rats. (A) Lactate dehydrogenase (LDH) activity, (B) Total protein level, $(C)$ Polymorphonuclear leukocyte $(P M N)$ count in bronchoalveolar lavage fluid (BALF). The values are expressed as a mean $\pm S E$ of pentaplicate samples.

$\mathbf{A}$

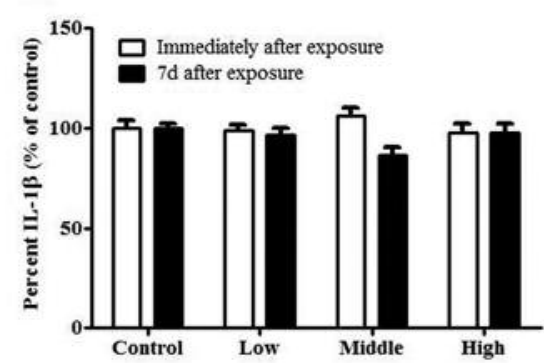

D

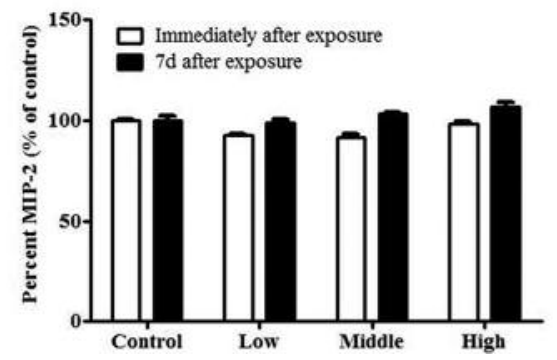

B

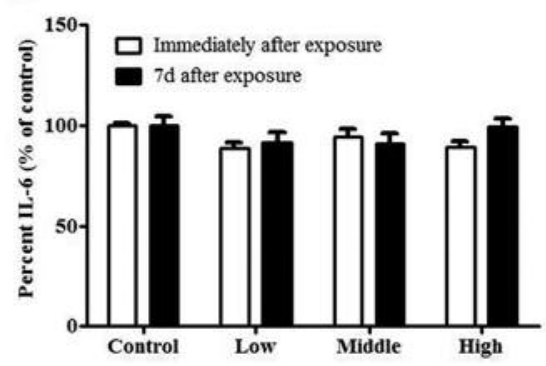

$\mathbf{E}$

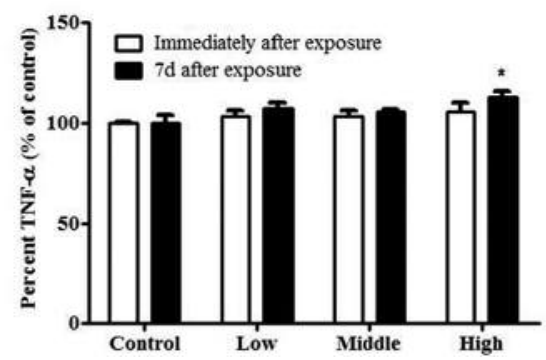

C

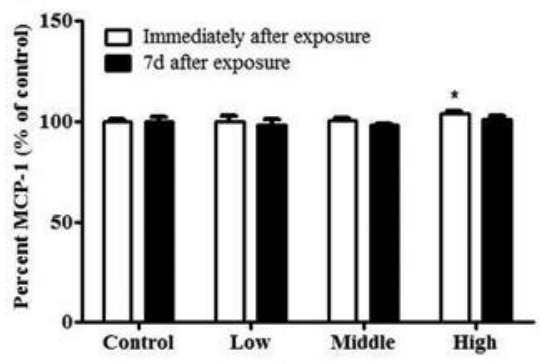

Figure 2. Change in pulmonary inflammation cytokines induced by glycolic acid in the acute inhalation test. (A) Interleukin-1beta (IL-1 $\beta)$, (B) Interleukin-6 (IL-6), (C) Monocyte chemoattractant protein-1 (MCP-1), (D) Macrophage inflammatory protein-2 (MIP-2), (E) Tumor necrosis factoralpha $(T N F-\alpha)$ in BALF. The values are expressed as a mean $\pm S E$ of pentaplicate samples.

inhalation exposure of humans to these chemicals is increasing, it is very important to identify the inhalation toxicities of chemicals (29). There are only few inhalation studies of glycolic acid $(10,30)$. For a chemical risk assessment, a 28-day repeated toxicity study is usually required (31-33). However, there is no reported 28-day inhalation study of glycolic acid. Therefore, to confirm the safety of glycolic acid, we conducted acute and 28-day repeated inhalation studies.

\section{Materials and Methods}

Chemicals. Glycolic acid (Cas no. 79-14-1) was purchased from Sigma-Aldrich (St. Louis, MO, USA).

Animals. Specific-pathogen-free (SPF) male Sprague-Dawley (sixweek-old) rats were purchased from Orient Bio Inc., (Sungnam, South Korea). The temperature of the animal rooms was set to $22^{\circ} \mathrm{C} \pm 3^{\circ} \mathrm{C}$ and $50 \% \pm 20 \%$ relative humidity; a $12: 12$ hour light/dark cycle was used. A laboratory diet (LabDiet 5053, Orient 
Table I. Summary of the histopathological results of rats after acute inhalation of glycolic acid.

\begin{tabular}{|c|c|c|c|c|}
\hline Organ/Histopathology Group & Control & Low & Middle & High \\
\hline \multicolumn{5}{|l|}{ Exposure groups } \\
\hline No. examined & 5 & 5 & 5 & 5 \\
\hline \multicolumn{5}{|l|}{ Nasal cavity } \\
\hline \multicolumn{5}{|l|}{ Level 1} \\
\hline No specific lesion & $4(80.0)$ & $5(100)$ & $4(80.0)$ & $5(100)$ \\
\hline Microcyst, intra-respiratory epithelium, present & $1(20.0)$ & $0(0.00)$ & $1(20.0)$ & $0(0.00)$ \\
\hline \multicolumn{5}{|l|}{ Level 4} \\
\hline No specific lesion & $5(100)$ & $4(80.0)$ & $5(100)$ & $5(100)$ \\
\hline Microcyst, intra-olfactory epithelium, present & $0(0.00)$ & $1(20.0)$ & $0(0.00)$ & $0(0.00)$ \\
\hline \multicolumn{5}{|l|}{ Lung } \\
\hline No specific lesion & $4(80.0)$ & $3(60.0)$ & $5(100)$ & $4(80.0)$ \\
\hline Alveolar macrophage aggregation, (multi)focal & $1(20.0)$ & $1(20.0)$ & $0(0.00)$ & $0(0.00)$ \\
\hline Grades: minimal & 1 & 1 & 0 & 0 \\
\hline Cell infiltration, mononuclear or mixed cells, perivascular & $0(0.00)$ & $1(20.0)$ & $0(0.00)$ & $1(20.0)$ \\
\hline Grades: minimal & 0 & 1 & 0 & 1 \\
\hline \multicolumn{5}{|l|}{ Recovery groups } \\
\hline No. examined & 5 & 5 & 5 & 5 \\
\hline \multicolumn{5}{|l|}{ Nasal cavity } \\
\hline \multicolumn{5}{|l|}{ Level 1} \\
\hline No specific lesion & $4(80.0)$ & $5(100)$ & $5(100)$ & $5(100)$ \\
\hline Microcyst, intra-respiratory epithelium, present & $1(20.0)$ & $0(0.00)$ & $0(0.00)$ & $0(0.00)$ \\
\hline \multicolumn{5}{|l|}{ Lung } \\
\hline No specific lesion & $3(60.0)$ & $4(80.0)$ & $4(80.0)$ & $1(20.0)$ \\
\hline Alveolar macrophage aggregation, (multi)focal & $0(0.00)$ & $0(0.00)$ & $1(20.0)$ & $1(20.0)$ \\
\hline Grades: minimal & 0 & 0 & 1 & 1 \\
\hline Cell infiltration, mononuclear or mixed cells, perivascular & $1(20.0)$ & $0(0.00)$ & $0(0.00)$ & $2(40.0)$ \\
\hline Grades: minimal & 1 & 0 & 0 & 2 \\
\hline Inflammatory cell infiltration, focal, alveolar & $1(20.0)$ & $0(0.00)$ & $0(0.00)$ & $0(0.00)$ \\
\hline Grades: minimal & 1 & 0 & 0 & 0 \\
\hline Pulmonary fibrosis, focal, alveolar & $0(0.00)$ & $1(20.0)$ & $0(0.00)$ & $1(20.0)$ \\
\hline Grades: minimal & 0 & 1 & 0 & 1 \\
\hline
\end{tabular}

The parentheses represent the percentage of the cases with the lesions of the total examined number of tissues.

Bio Inc., South Korea) and water were supplied ad libitum. Following an acclimatization period of 1 week, the rats were randomly divided into four groups (20 rats/group) for each of the acute and subacute glycolic acid exposure studies. The changes in body weight were recorded twice per week from the beginning of the study and clinical signs and symptoms were observed during the exposure period. All animal experiments were conducted in accordance with the guidelines of the Institutional Animal Care and Use Committee of the National Institute of Environmental Research (Republic of Korea).

Inhalation exposure. The inhalation aerosols of glycolic acid solutions were generated by using an atomizer with a clean air flow of $250 \mathrm{~L} / \mathrm{min}$. For the acute inhalation exposure study, the rats were exposed to: i) $20 \mathrm{mg} / \mathrm{m}^{3}$, ii) $100 \mathrm{mg} / \mathrm{m}^{3}$, and iii) $500 \mathrm{mg} / \mathrm{m}^{3}$ glycolic acid for 4 hours in the low, medium, and high exposure groups, respectively; the control rats were exposed to clean air. In each group of acute toxicity test, half of the rats were sacrificed immediately following exposure; the recovery of the remaining rats was monitored for 7 days following exposure and they were then euthanized. For the subacute toxicity study, the rats were exposed to: i) $2 \mathrm{mg} / \mathrm{m}^{3}$, ii) $10 \mathrm{mg} / \mathrm{m}^{3}$, and iii) $50 \mathrm{mg} / \mathrm{m}^{3}$ glycolic acid for 6 hours/day, 5 days/week, for 28 days in the low, medium, and high exposure groups, respectively. In each group of subacute toxicity test, half of the rats were sacrificed 1 day following exposure; the recovery of the remaining rats was monitored for 7 days following exposure and they were subsequently euthanized.

Glycolic acid monitoring. Temperature, humidity, air flow, and air pressure were monitored during exposure by using a Model VT3X15 environmental controller (Sibata Scientific Technology Ltd, Saitama, Japan). The concentration of glycolic acid was monitored by sampling the chamber air using a SIP-32L (SIBATA) and comparing the weight of the membranes (T60A20, Ф55). The mass 


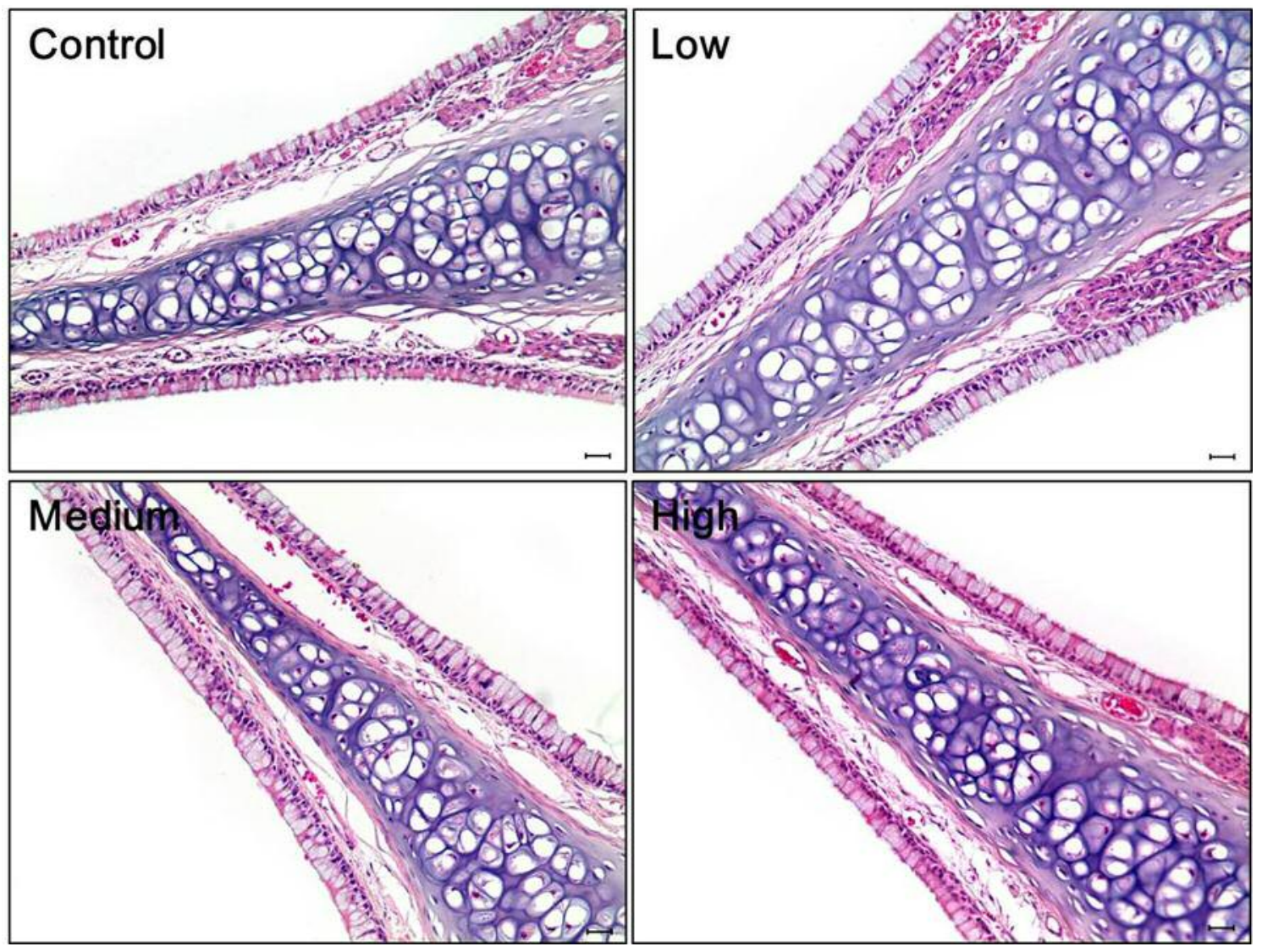

Figure 3. Histological features of the respiratory epithelial area of the nasal cavity in each group of rats in the acute inhalation study. No treatmentrelated abnormal findings were noted in the rats exposed to: i) $20 \mathrm{mg} / \mathrm{m}^{3}$ (low), ii) $100 \mathrm{mg} / \mathrm{m}^{3}$ (medium), and iii) $500 \mathrm{mg} / \mathrm{m}^{3}$ (high) of glycolic acid after inhalation for 4 hours. $H \& E$. Scale bars $=25 \mu \mathrm{m}$.

median aerodynamic diameter (MMAD) and the geometric standard deviation (GSD) of glycolic acid in the exposure chamber were measured using an Andersen cascade impactor (AN-200 Sibata Science Technology, Japan).

Hematology. Blood samples were collected through the abdominal aorta following anesthesia, and were transferred to tubes containing trisodium EDTA as anticoagulant. Hematological analyses were performed using an automatic hematological analyzer (LC-662G, Kyoto, Japan). The test parameters were: i) white blood cells (WBCs), ii) red blood cells (RBCs), iii) hemoglobin (Hgb), hematocrit (Hct), iv) mean corpuscular volume (MCV), v) mean corpuscular hemoglobin $(\mathrm{MCH})$, vi) mean corpuscular hemoglobin concentration (MCHC), vii) red blood cell volume distribution width (RDW), viii) platelets (PLT), ix) mean platelet volume (MPV), x) plateletcrit (PCT), and xi) plate volume distribution width (PDW).

Serum biochemistry. Blood samples were centrifuged at $2000 \mathrm{rpm}$ for 10 minutes. An autoanalyzer (FUJI DRI-CHEM 4000ie, Tokyo, Japan) was used to determine the concentrations of: i) triglyceride (TG), ii) total cholesterol (T-CHO), iii) glutamic-oxaloacetic transaminase (GOT), iv) lactate dehydrogenase (LDH), v) glucose
(GLU), vi) alkaline phosphatase (ALP), vii) glutamic-pyruvic transaminase (GPT), viii) total bilirubin (T-BIL), ix) albumin $(\mathrm{ALB}), \mathrm{x})$ creatinine $(\mathrm{CRE})$, and $\mathrm{xi}$ ) blood urea nitrogen (BUN).

Analysis of bronchoalveolar lavage fluid (BALF). BALF from five rats in each group was analyzed as described in a previous study (34). Briefly, the rat lungs were lavaged three times with $4 \mathrm{~mL}$ calciumand magnesium-free phosphate-buffered saline (PBS, pH 7.4). The BALF was centrifuged at $1,500 \mathrm{rpm}$ for 10 minutes in a Hanil Union $32 \mathrm{R}$ centrifuge (Incheon, Korea) to separate the supernatant from the cells. The supernatants were stored at $-80^{\circ} \mathrm{C}$ prior to the assay. The cell pellets were counted by using a Vi-Cell ${ }^{\circledR} \mathrm{XR}$ analyzer (Beckman Coulter, Brea, CA, USA) and diluted to $2 \times 10^{5}$ cells $/ \mathrm{mL} ; 50 \mu \mathrm{L}$ was placed on a slide by using Shandon Cytospin (Shandon, Pittsburgh, PA, USA) and the slides were stained with Diff-Quik (International Reagents, Kobe, Japan). The supernatant was used for the analysis of total protein, $\mathrm{LDH}$, and inflammatory cytokine levels. The total protein (TP) and LDH levels were determined using a bicinchoninic acid (BCA) protein assay kit (Intron Biotechnology, Korea) and an EZ-LDH Cell Cytotoxicity Assay Kit (Daeil Lab Service, Korea), respectively. To evaluate the inflammatory cytokine levels, ELISA kits for tumor necrosis factor-alpha (TNF- $\alpha$ ), interleukin-1beta (IL$1 \beta$ ), interleukin-6 (IL-6), and monocyte chemoattractant protein-1 


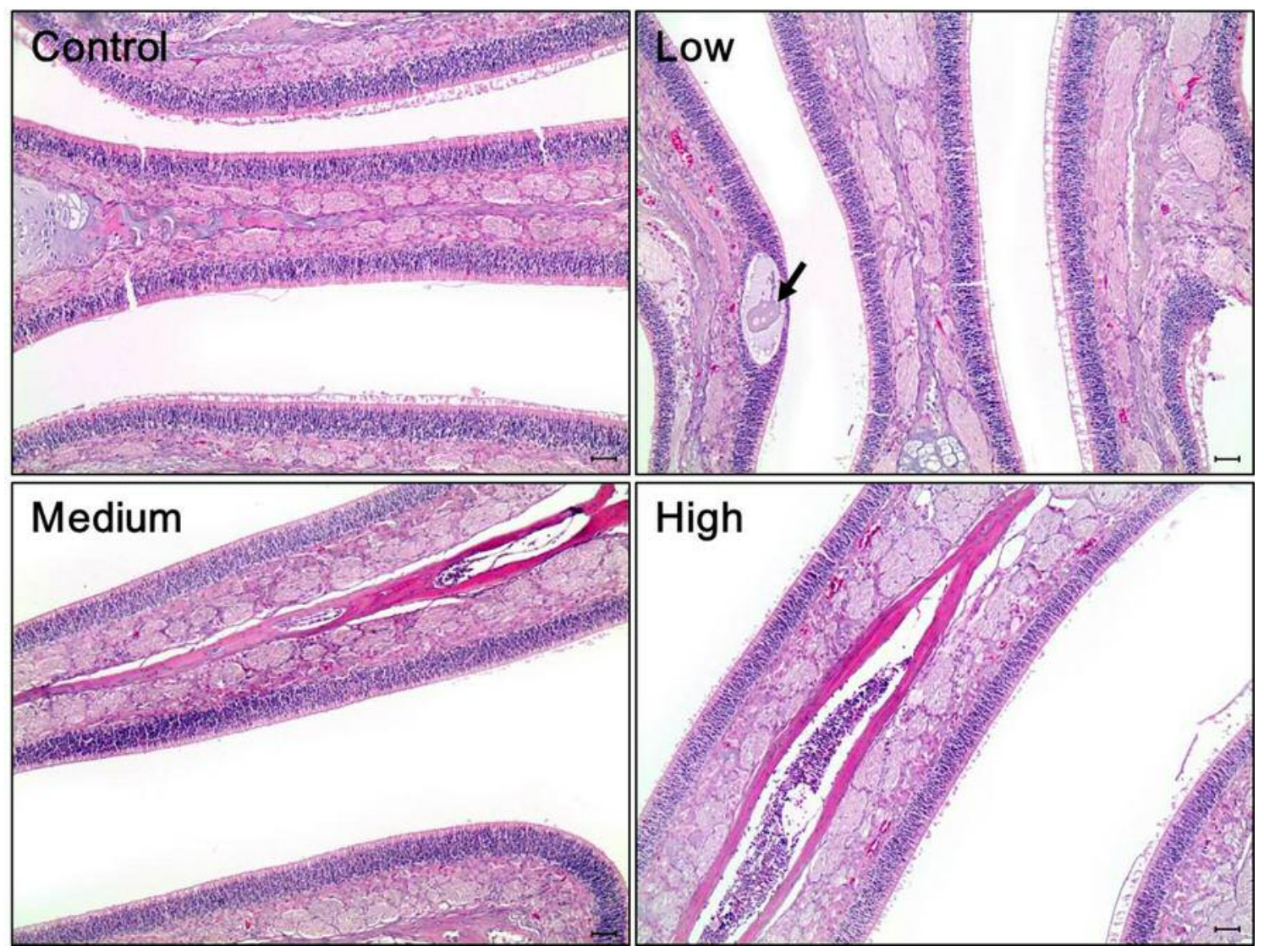

Figure 4. Histological features of the olfactory epithelial areas of the nasal cavity in each group of rats in the acute inhalation study. No treatmentrelated abnormal findings were noted in the rats exposed to: i) $20 \mathrm{mg} / \mathrm{m}^{3}$ (low), ii) $100 \mathrm{mg} / \mathrm{m}^{3}$ (medium), and iii) $500 \mathrm{mg} / \mathrm{m}^{3}$ (high) concentrations of glycolic acid after inhalation for 4 hours. Note an intraepithelial microcyst (arrow). H\&E staining. Scale bars=25 $\mu \mathrm{m}$.

(MCP-1) were purchased from R\&D systems (Minneapolis, MN, USA), and for macrophage inflammatory protein-2 (MIP-2) from Invitrogen (Carlsbad, CA, USA).

Histopathological analysis. Following the inhalation of glycolic acid for 4 weeks, the animals were euthanized. After gross examination, the lung and nasal cavity were fixed in $10 \%$ neutral buffered formalin. The nasal cavity was decalcified with a decalcification solution and then cross-sectioned into four section-levels: i) level 1 (posterior part of the upper incisors), ii) level 2 (incisive papilla), iii) level 3 (second palatine crest) and iv) level 4 (first upper molar teeth). Following the routine tissue processing, the tissues were embedded in paraffin and $3 \mu \mathrm{m}$ slices were cut. The sections were stained with hematoxylin and eosin (H\&E) for histological examination under a light microscope (Olympus BX41, Tokyo, Japan). The lesions were graded, depending on severity by pathologists.

Statistical analysis. Statistical analyses were computed by using GraphPad Prism version 5.01 (GraphPad Software Inc., USA). The values were expressed as the mean \pm standard error (SE). A one-way multiple variance of analysis (ANOVA) test, followed by Student's $t$ test was used to compare the exposure groups with the control group and to observe whether the $p$-Value was less than 0.05 , or 0.01 .

\section{Results}

Acute inhalation study. In the acute inhalation study, the actual exposure concentration of glycolic acid was determined as: i) $18.1 \pm 1.53 \mathrm{mg} / \mathrm{m}^{3}$, ii) $100 \pm 3.46 \mathrm{mg} / \mathrm{m}^{3}$, and iii) $458.3 \pm 2.89$ $\mathrm{mg} / \mathrm{m}^{3}$ in the low, medium, and high exposure groups, respectively. The mass median average diameter (MMAD) and geometric standard deviation (GSD) determined by the multistage impactor were in the range of 1.74-3.08 $\mu \mathrm{m}$ and 2.512.87 in each chamber, which matched the conditions of the OECD Test Guideline for Chemicals (35). There were no significant changes in body weight or the lung, liver, and kidney weights of the rats in the exposed groups compared to the control group (data not shown). The results of hematology and serum biochemistry, as well as gross observations showed no significant differences between the control and glycolic acid-exposed groups (data not shown).

The BALF samples of the rats were analyzed after the rats were necropsied. No differences in the LDH levels were identified in the exposure groups (autopsied immediately 


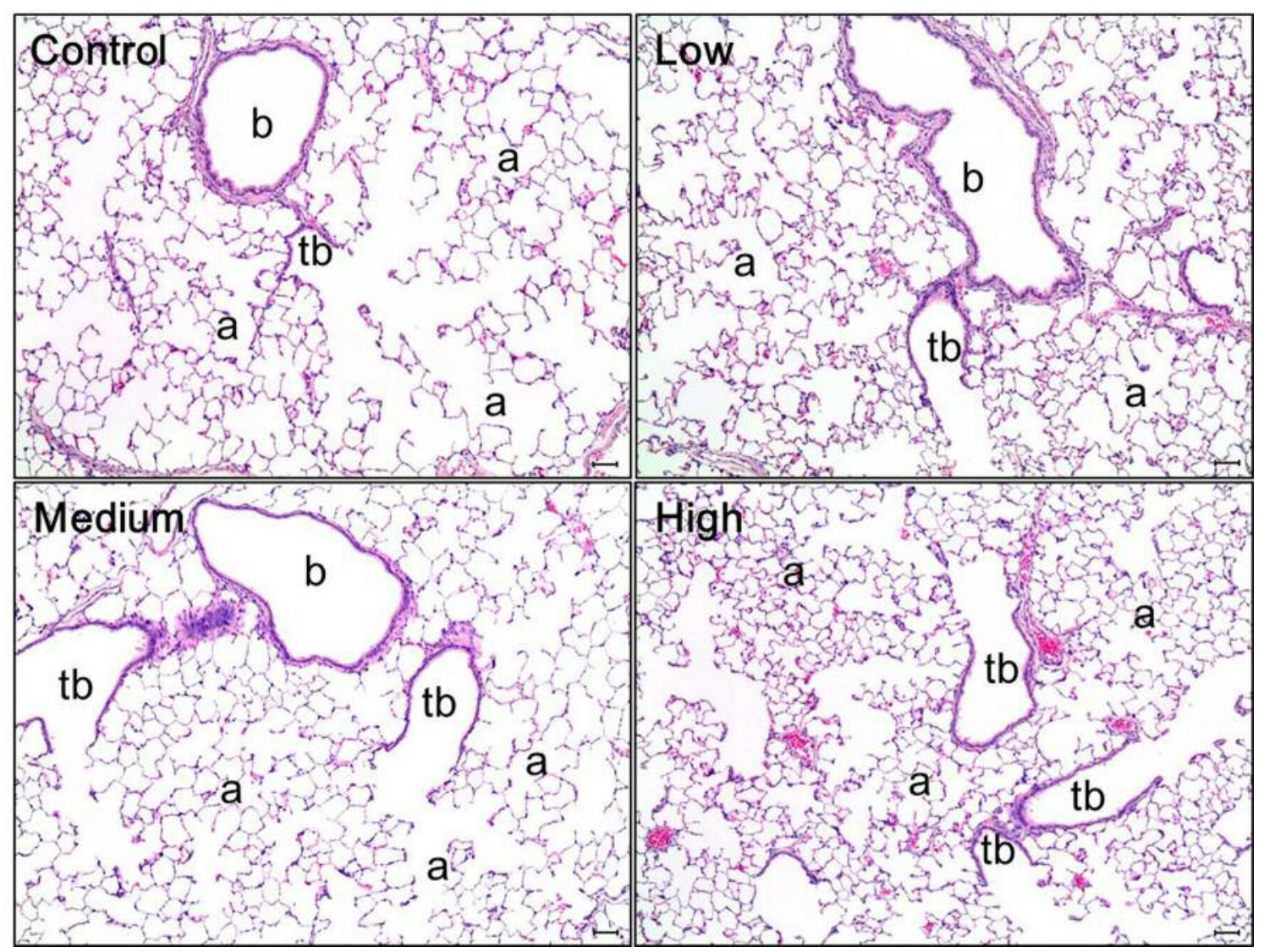

Figure 5. Histological features of representative lungs of each group of rats in the acute inhalation study. No treatment-related abnormal findings were noted in the lungs of the rats exposed to: i) $20 \mathrm{mg} / \mathrm{m}^{3}$ (low), ii) $100 \mathrm{mg} / \mathrm{m}^{3}$ (medium), and iii) $500 \mathrm{mg} / \mathrm{m}^{3}$ (high) of glycolic acid by inhalation for 4 hours. $b$, bronchiole; tb, terminal bronchiole; a, alveoli. H\&E staining. Scale bars $=50 \mu \mathrm{m}$.

after the final exposure) or the recovery groups (autopsied 7 days after the final exposure) (Figure 1A). The BALF TP levels increased in the high-exposure and recovery groups, but the difference was not statistically significant (Figure 1B). An increase in polymorphonuclear leukocytes (PMNs) in the high-exposure and recovery groups was detected (Figure 1C). A slight increase was also detected for TNF- $\alpha$ in the high-recovery group and for MCP-1 in the highexposure group. There were no significant changes in IL-1 $\beta$, IL-6, and MIP-2 among all groups (Figure 2).

The results of the histopathological examinations of the nasal cavity and lung in the acute inhalation toxicity are presented in Table I. There were no adverse findings in the nasal cavity or lungs of rats subjected to the acute inhalation of glycolic acid (Figures 3-5). Microcysts in the respiratory epithelium of level 1 sections were found in one rat in the control group and in the medium exposure group. This was not thought to be related to the inhalation of glycolic acid, because it was considered to be related to the accumulation of secretion from the mucous gland and also occurred in the control group. The microcysts of the olfactory epithelium of level 4 sections were evident in one rat in the low exposure group. The cause of the microcysts in level 4 sections was not clear, but it was also thought to be due to the accumulation of secretion. It was also not considered to be related to glycolic acid because there was no dose dependency. No adverse effects in the nasal cavity were observed in the recovery groups. In the lungs of rats, no specific adverse findings were evident, although focal alveolar macrophage aggregation, mononuclear cell filtration, focal inflammatory cell infiltration, and focal alveolar fibrosis were observed in both the exposure and recovery groups. In the case of fibrosis, it was found in only one focal site in the lungs of one rat out of five in the low and high dose groups without dose-dependency. Thus, this lesion was not considered related to the treatment of glycolic acid (Table I).

Subacute inhalation study. To evaluate the inhalation toxicity of glycolic acid in rats, an inhalation study of glycolic acid was 
A

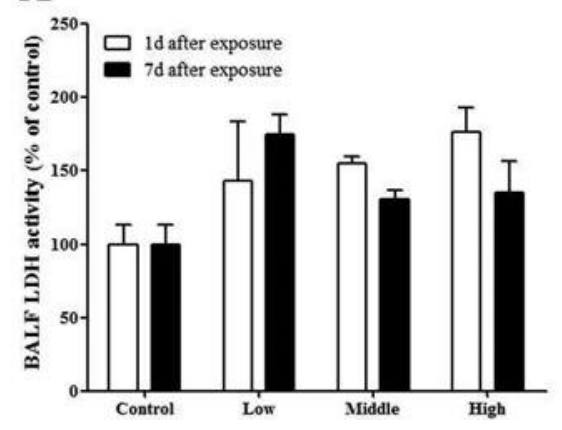

B

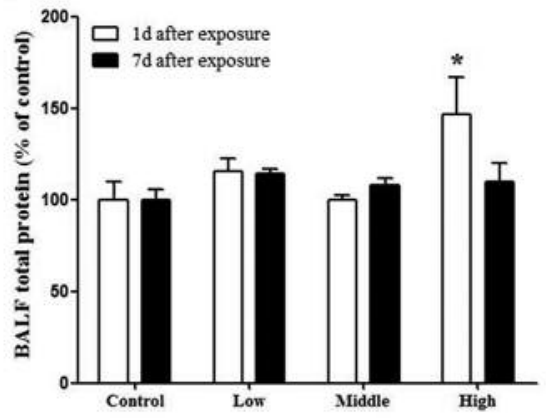

C

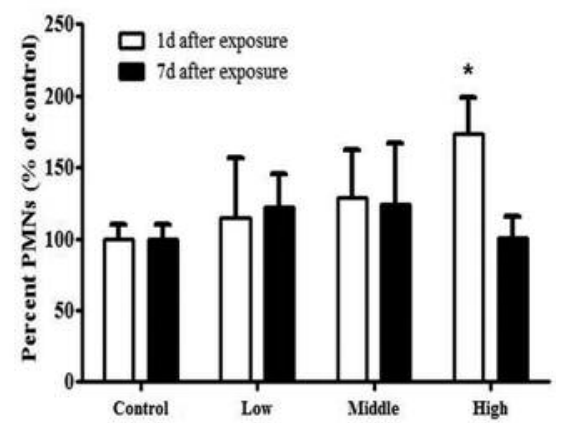

Figure 6. The pulmonary toxicities induced by subacute inhalation test of the glycolic acid in rats. (A) Lactate dehydrogenase (LDH) activity, (B) Total protein level, (C) Polymorphonuclear leukocyte (PMN) count in BALF. The values are expressed as a mean $\pm S E$ of pentaplicate samples.

A

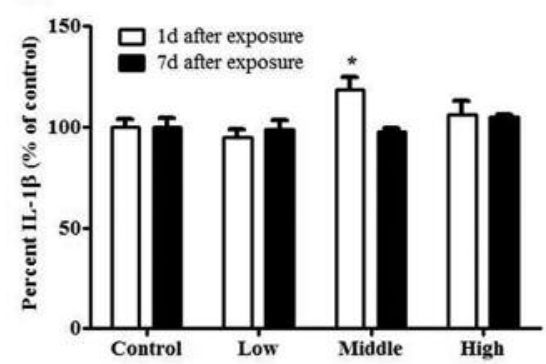

D

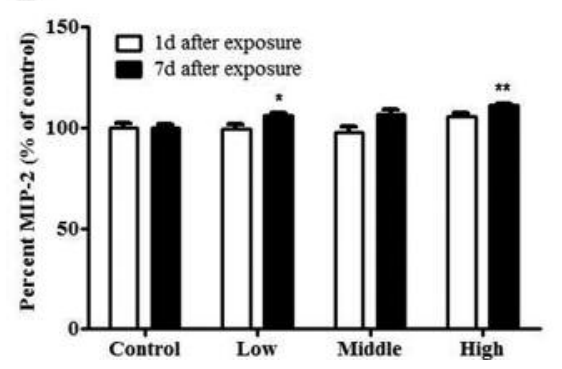

B

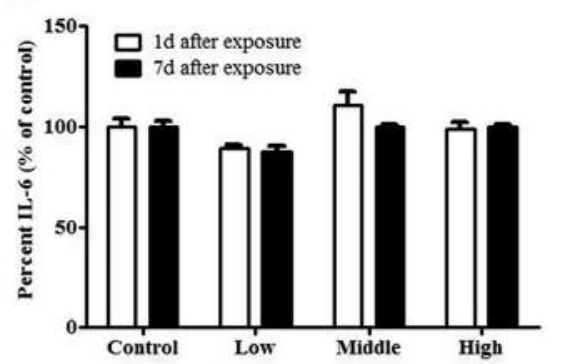

$\mathbf{E}$

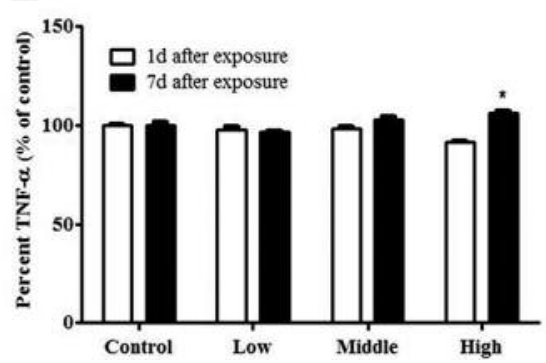

C

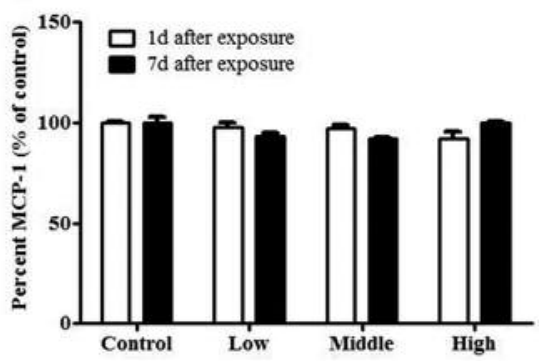

Figure 7. Changes in pulmonary inflammatory cytokines induced by glycolic acid in the subacute inhalation test. (A) Interleukin-1beta (IL-1 $\beta)$, (B) Interleukin-6 (IL-6), (C) Monocyte chemoattractant protein-1 (MCP-1), (D) Macrophage inflammatory protein-2 (MIP-2), (E) Tumor necrosis factoralpha $(T N F-\alpha)$ in BALF. The values are expressed as a mean \pm SE of pentaplicate samples.

conducted for 28 days. The actual exposure concentrations of glycolic acid were determined as: i) $2.35 \pm 0.46 \mathrm{mg} / \mathrm{m}^{3}$, ii) $9.9 \pm 1.79 \mathrm{mg} / \mathrm{m}^{3}$, and iii) $49.5 \pm 8.5 \mathrm{mg} / \mathrm{m}^{3}$ in the low, medium, and high exposure groups, respectively. The particle sizes of glycolic acid were determined using a multi-stage impactor. The MMAD and GSD were in the range of 0.87-1.82 $\mu \mathrm{m}$ and 1.9-2.57 in each chamber, which matched the conditions of the OECD Test Guideline for Chemicals.

There were no significant changes in body weight or in the lung, liver and kidney weights of rats in the exposed groups compared to the control group (data not shown). No changes in hematology, serum biochemistry, and gross observation were found during the autopsy on rats (data not shown).

The LDH levels in BALF followed an increasing trend in the exposure groups (autopsied 1 day after the final exposure) and the recovery groups (autopsied 7 days after the final exposure), but the changes were not statistically significant (Figure 6A). The TP and PMNs significantly increased in the high-exposure group and returned to normal during the recovery period (Figure $6 \mathrm{~B}$ and $6 \mathrm{C}$ ). No 


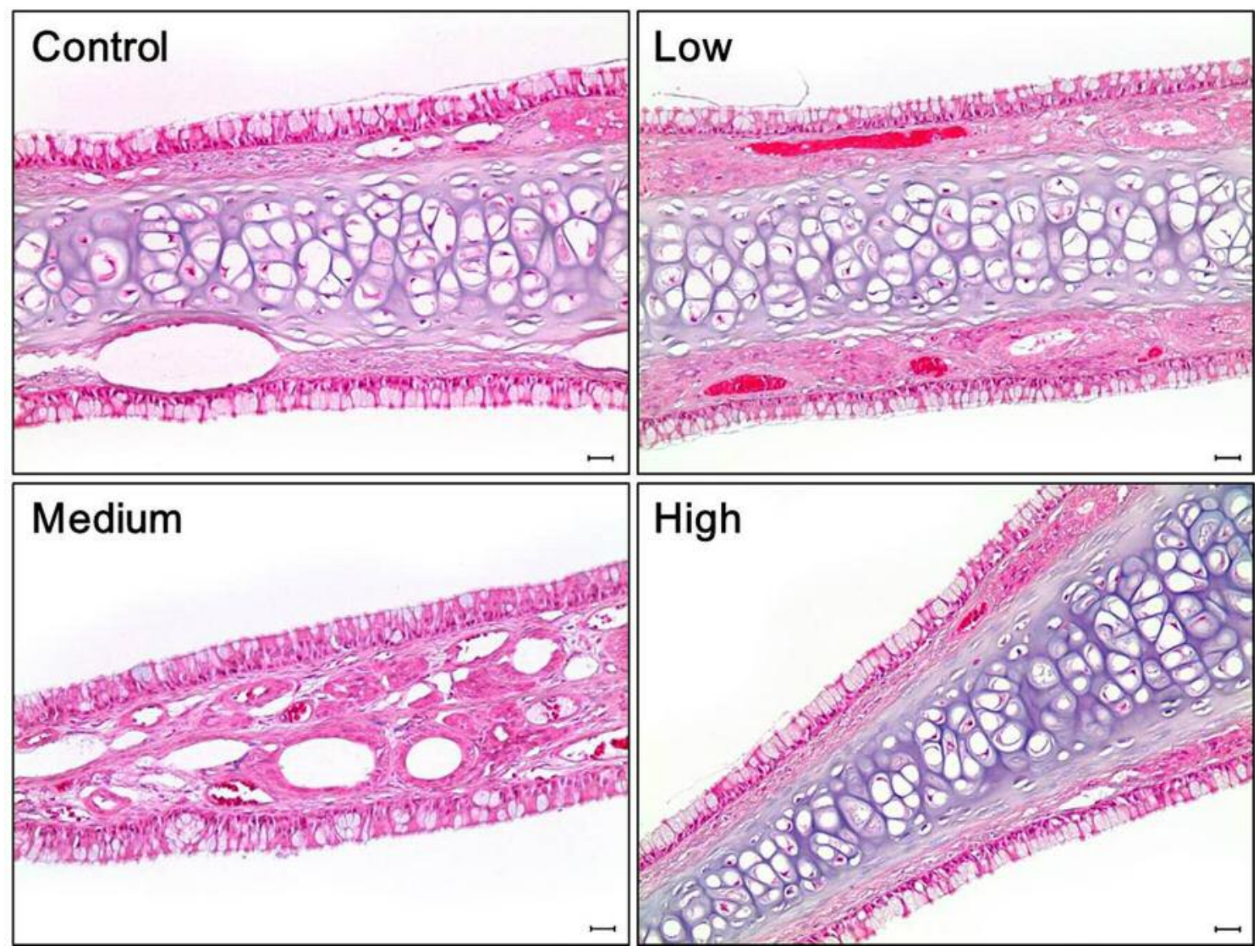

Figure 8. Histological features of the respiratory epithelial area of the nasal cavity in each group of rats in the 28-day inhalation study. No treatmentrelated abnormal findings were noted in the rats exposed to: i) $2 \mathrm{mg} / \mathrm{m}^{3}$ (low), ii) $10 \mathrm{mg} / \mathrm{m}^{3}$ (medium), and iii) $50 \mathrm{mg} / \mathrm{m}^{3}$ (high) of glycolic acid for 6 hours/day, 5 days/week for 28 days. $H \& E$ staining. Scale bars $=25 \mu \mathrm{m}$.

significant difference among groups was found for IL-6 and MCP-1 in BALF in the exposure and recovery groups, but slight increases in IL-1 $\beta$, TNF- $\alpha$, and MIP-2 were detected in medium-exposure, high-recovery, and low- and highrecovery groups, respectively (Figure 7).

The results of the histopathological examinations of the nasal cavity and the lungs of rats exposed to subacute inhalation toxicity are presented in Table II. No effects related to glycolic acid were observed in the nasal cavity and the lung (Figures 8-10). Microcysts of the respiratory epithelium in level 1 sections were found in the lowexposure and high-recovery groups, but also in the control group, thus they were not considered to be the result of glycolic acid treatment (Table II). Alveolar macrophage aggregation and the preivascular infiltration of mononuclear cells were often observed in the lungs of rats in the exposure and recovery groups. However, it was minimal in severity and also occurred in the control group (Table II). Vascular mineralization found in the lungs is a finding that is often observed in normal rats (36).

\section{Discussion}

Glycolic acid is used in consumer products, such as cosmetics and cleaning products, and may be used in spray products (37). Although the vapor pressure of glycolic acid is not high, there is the possibility of inhalation exposure (38). We conducted inhalation studies on glycolic acid to identify nasal and pulmonary toxicities.

There were no deaths in any of the glycolic acid-treated groups in the acute and subacute inhalation studies; moreover, no changes occurred in body weight, organ weight, hematology, and serum biochemistry. The results of histopathologic analysis of the nasal cavities and lungs of the rats subjected to acute and subacute inhalation studies also showed no toxic effects of glycolic acid, although microcysts in the nasal cavity, alveolar macrophage aggregation, perivascular cell infiltration, pulmonary fibrosis, and vascular mineralization were often found, irrespective of the exposure to glycolic acid.

In the acute inhalation experiment, the PMNs, TNF- $\alpha$, and MCP-1 in BALF significantly increased in the high- 
Table II. Summary of the histopathological results of rats after subacute inhalation of glycolic acid.

\begin{tabular}{|c|c|c|c|c|}
\hline Organ/Histopathology Group & Control & Low & Middle & High \\
\hline \multicolumn{5}{|l|}{ Exposure groups } \\
\hline No. examined & 5 & 5 & 5 & 5 \\
\hline \multicolumn{5}{|l|}{ Nasal cavity } \\
\hline \multicolumn{5}{|l|}{ Level 1} \\
\hline No specific lesion & $4(80.0)$ & $3(60.0)$ & $5(100)$ & $5(100)$ \\
\hline Microcyst, intra-respiratory epithelium, present & $1(20.0)$ & $2(40.0)$ & $0(0.00)$ & $0(0.00)$ \\
\hline \multicolumn{5}{|l|}{ Lung } \\
\hline No specific lesion & $2(40.0)$ & $4(80.0)$ & $1(20.0)$ & $2(40.0)$ \\
\hline Alveolar macrophage aggregation, (multi)focal & $1(20.0)$ & $0(0.00)$ & $2(40.0)$ & $2(40.0)$ \\
\hline Grades: minimal & 1 & 0 & 2 & 2 \\
\hline Cell infiltration, mononuclear or mixed cells, perivascular & $2(40.0)$ & $1(20.0)$ & $1(20.0)$ & $2(40.0)$ \\
\hline Grades: minimal & 2 & 1 & 1 & 2 \\
\hline Vascular mineralization, focal & $0(0.00)$ & $0(0.00)$ & $0(0.00)$ & $1(20.0)$ \\
\hline Grades: minimal & 0 & 0 & 0 & 1 \\
\hline \multicolumn{5}{|l|}{ Recovery groups } \\
\hline No. examined & 5 & 5 & 5 & 5 \\
\hline \multicolumn{5}{|l|}{ Nasal cavity } \\
\hline \multicolumn{5}{|l|}{ Level 1} \\
\hline No specific lesion & $4(80.0)$ & $5(100)$ & $5(100)$ & $4(80.0)$ \\
\hline Microcyst, intra-respiratory epithelium, present & $1(20.0)$ & $0(0.00)$ & $0(0.00)$ & $1(20.0)$ \\
\hline \multicolumn{5}{|l|}{ Lung } \\
\hline No specific lesion & $3(60.0)$ & $3(60.0)$ & $4(80.0)$ & $2(40.0)$ \\
\hline Alveolar macrophage aggregation, (multi)focal & $0(0.00)$ & $0(0.00)$ & $1(20.0)$ & $2(40.0)$ \\
\hline Grades: minimal & 0 & 0 & 1 & 2 \\
\hline Cell infiltration, mononuclear or mixed cells, perivascular & $2(40.0)$ & $2(40.0)$ & $1(20.0)$ & $1(20.0)$ \\
\hline Grades: minimal & 2 & 2 & 1 & 1 \\
\hline Vascular mineralization, focal & $0(0.00)$ & $0(0.00)$ & $0(0.00)$ & $1(20.0)$ \\
\hline Grades: minimal & 0 & 0 & 0 & 1 \\
\hline
\end{tabular}

The parentheses represent the percentage of the cases with the lesions of the total examined number of tissues.

concentration groups. The changes in TNF- $\alpha$ and MCP-1 were considered minor and not significant. In the subacute (28-day) inhalation test, the increased TP and PMNs in BALF returned to normal during the recovery period. Changes in cytokines (IL-1 $\beta$, MIP-2, and TNF- $\alpha$ ) were observed in the exposure and recovery groups, but the extent of changes was considered minor and they were not significant. Recently, a 2-week inhalation study of sodium metabisulfite was reported (34). Sodium metabisulfite produces a corrosive acid when this is mixed with water (39). Similar to the results in our studies, sodium metabisulfite did not cause changes of inflammatory cytokines (TNF- $\alpha$, IL- 6 , TGF- $\beta 1$, IL- $1 \beta$ and MCP- 1 ) at the highest concentration tested $\left(110 \mathrm{mg} / \mathrm{m}^{3}\right)(34)$.

Many studies have shown that acid inhalation causes lung damage, such as the development of pulmonary edema (40, 41). A 2-week inhalation study has determined the NOAEC of glycolic acid as $160 \mathrm{mg} / \mathrm{m}^{3}$ (30). Similar to the results from our study, no histopathological changes were found in rats subjected to glycolic acid inhalation. An increase in the lung/body weight ratio was found in the lowest concentration group. The most sensitive target organ of glycolic acid is the kidney $(6,12)$. Oxalate, a metabolite of glycolic acid, causes the formation of kidney stones and other nephrotoxicities (8). Renal toxicities, including kidney stones, result in the increase of serum BUN and creatinine $(13,42)$. In our study, no changes in serum BUN, creatinine, and kidney weight were found. Therefore, we believe that kidney toxicity did not occur in our study, although kidney toxicity was not evaluated in detail.

Glycolic acid is a weak acid (4). The $\mathrm{pH}$ of the airway surface liquid is endogenously regulated by acid and base secretion mechanisms $(43,44)$. However, many studies have reported that the inhalation exposure to acids can cause alteration of clearance function from the alveolar region (45). 


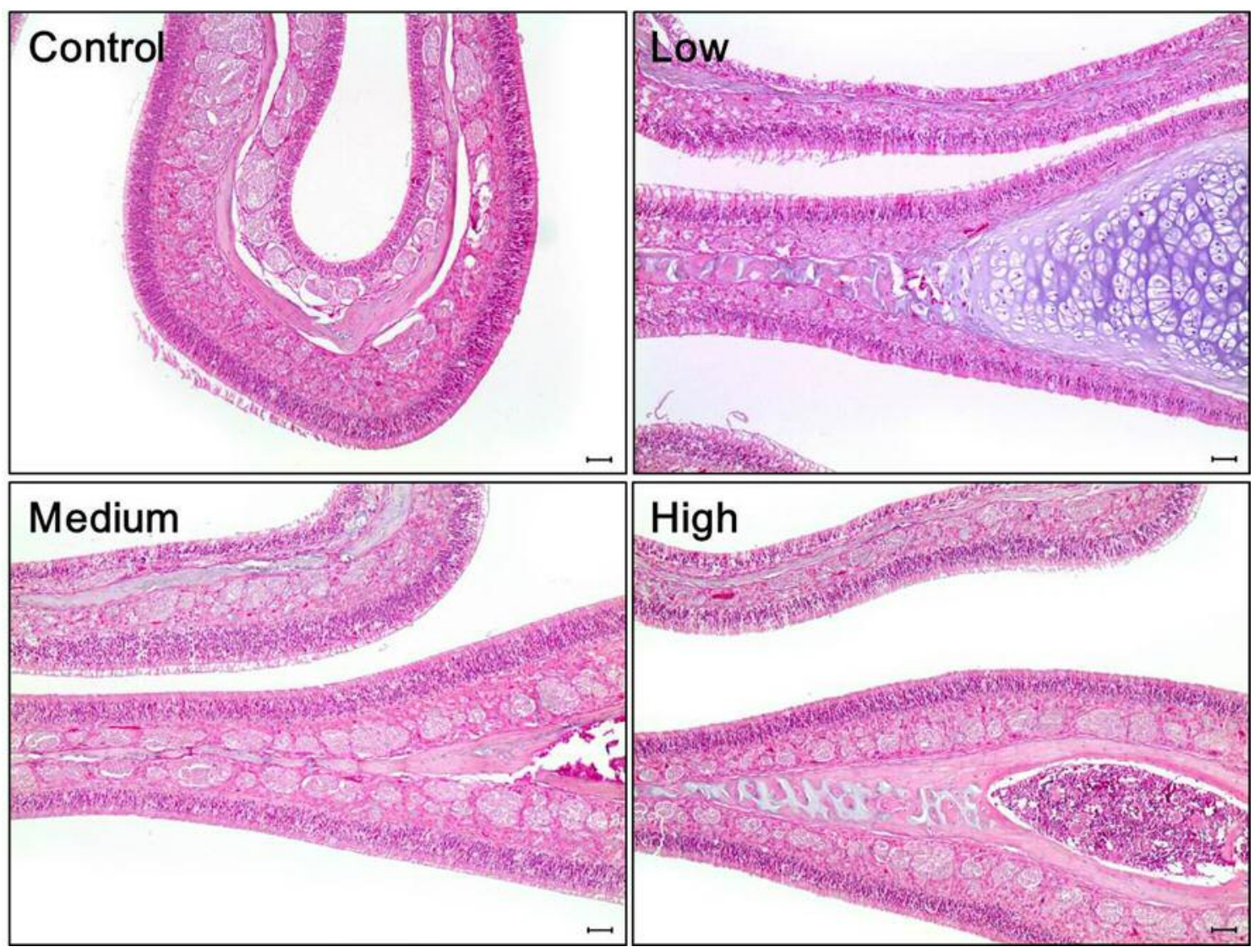

Figure 9. Histological features of the olfactory epithelial area of the nasal cavity in each group of rats in the 28-day inhalation study. No treatmentrelated abnormal findings were noted in the rats exposed to: i) $2 \mathrm{mg} / \mathrm{m}^{3}$ (low), ii) $10 \mathrm{mg} / \mathrm{m}^{3}$ (medium), and iii) $50 \mathrm{mg} / \mathrm{m}^{3}$ (high) of glycolic acid for 6 hours/day, 5 days/week, for 28 days. H\&E staining. Scale bars $=25 \mu \mathrm{m}$.

Thus, the inhalation of acids is associated with respiratory diseases, such as asthma, bronchitis, bronchoconstriction, bronchial hyperresponsiveness, and microvascular leakage (46-50). Hence, high concentrations of glycolic acid may cause respiratory diseases.

At present, no inhalation risk assessment has been performed for glycolic acid. For this, exposure assessment should be conducted through further studies. Glycolic acid is a major metabolite of ethylene glycol (11). Recently, it was reported that the NOAEC of ethylene glycol was 100 $\mathrm{mg} / \mathrm{m}^{3}$, the highest concentration tested, in a 4-week inhalation study (2). The metabolic pathway of glycolic acid is included in that of ethylene glycol (12), which shows the need for a mixture risk assessment of ethylene glycol and glycolic acid combined.

Several studies have reported that the toxicity of didecyldimethylammonium chloride (DDAC) is potentiated by ethylene glycol in bronchial epithelial cells (BEAS-2B) and intratracheally instilled rats $(51,52)$. These have confirmed that ethylene glycol amplifies the pulmonary toxicity of DDAC, including LDH, PMNs, and cytokines in BALF. This study shows the possibility that glycolic acid, a metabolite of ethylene glycol, can also potentiate the toxicity of other substances (52).

We suggest that the NOAEC for nasal and pulmonary toxicity of glycolic acid is over $50 \mathrm{mg} / \mathrm{m}^{3}$, the highest concentration in this 28-day inhalation study. The results of our study here, including those from hematology, serum biochemistry, BALF analysis, and histopathology, showed that the glycolic acid-related toxicities have not been clearly identified in the high concentration groups in acute and subacute inhalation studies. Therefore, to confirm the toxicities of glycolic acid, it is necessary for further studies to conduct inhalation tests at higher concentrations or for longer periods of time. Furthermore, we suggest that the mixture risk assessment for glycolic acid and ethylene glycol should be performed, and further studies need to be conducted to determine the potentiation effect of glycolic acid. 


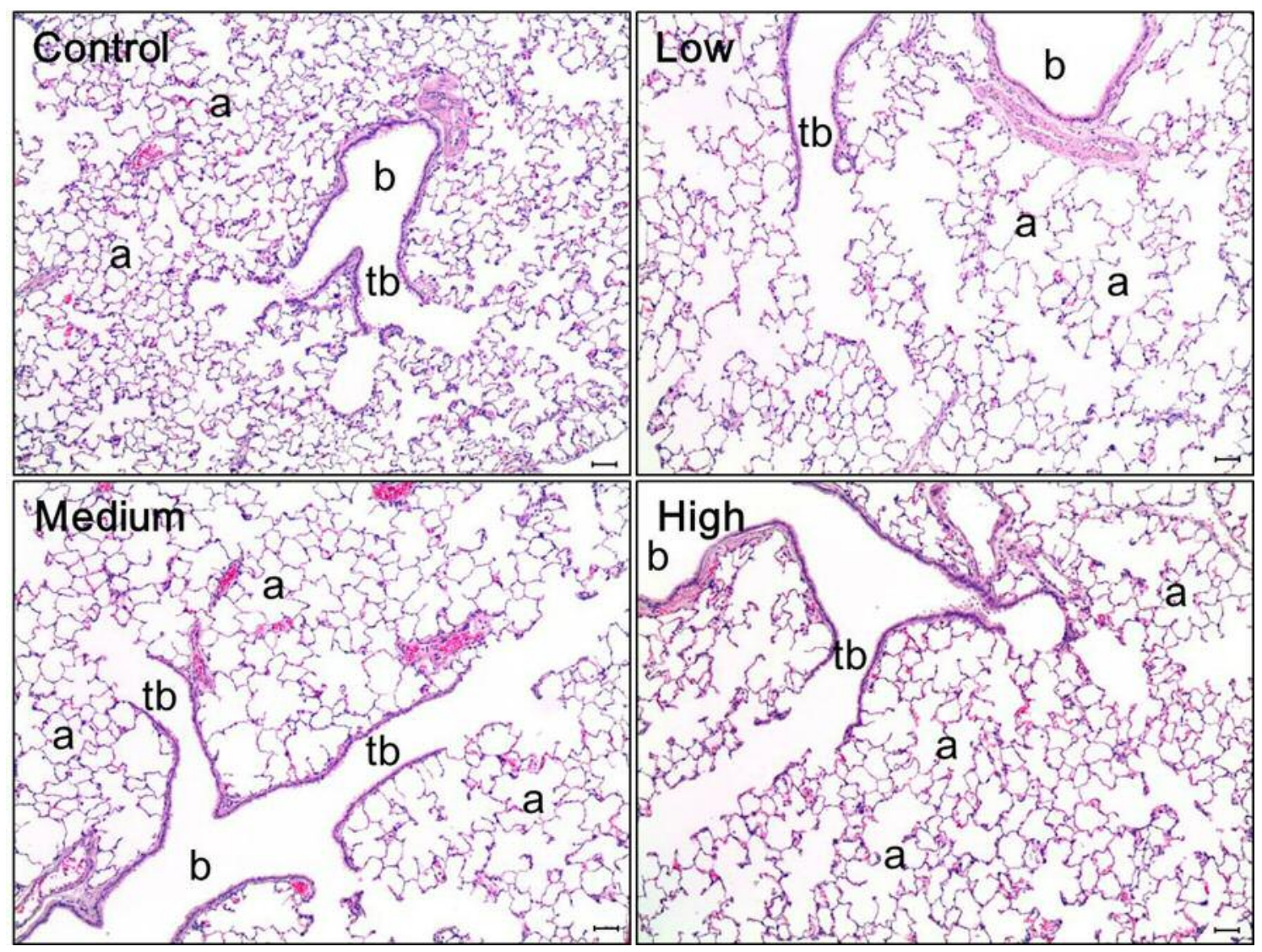

Figure 10. Histological features of representative lungs of each group of rats in the 28-day inhalation study. No treatment-related abnormal findings were noted in the lungs of the rats exposed to: i) $2 \mathrm{mg} / \mathrm{m}^{3}$ (low), ii) $10 \mathrm{mg} / \mathrm{m}^{3}$ (medium), and iii) $50 \mathrm{mg} / \mathrm{m} 3$ (high) of glycolic acid for 6 hours/day, 5 days/week for 28 days. $b$, bronchiole; tb, terminal bronchiole; a, alveoli. $H \& E$ staining. Scale bars $=50 \mu m$.

\section{Conflicts of Interest}

There are no conflicts of interest to declare.

\section{Authors' Contribution}

PK, SDY, and IS conceived and designed this study. SKL, BIY, and ICE wrote the manuscript. SKL, JY, HK, WK, IS, and ICE did experiments of cytotoxicity and inhalation toxicity. BIY performed the experiments of histopathology in rats.

\section{Acknowledgements}

This work was supported by the National Institute of Environmental Research, Republic of Korea (NIER-2018-03-001).

\section{References}

1 Hahn S, Schneider K, Gartiser S, Heger W and Mangelsdorf I: Consumer exposure to biocides--identification of relevant sources and evaluation of possible health effects. Environ Health 9: (7, 2010. PMID: 20128903. DOI: 10.1186/1476-069X-9-7
2 Kim H, Kwon J, Shim I, Kwon D, Lim Y, Kim E, Kim P and Choi K: Inhalation toxicity of ethylene glycol in rat. Journal of Veterinary Science and Technology 7(1), 2016. DOI: 10.4172/2157-7579.1000292

3 Harris KS and Richardson KE: Glycolate in the diet and its conversion to urinary oxalate in the rat. Invest Urol 18(2): 106109, 1980. PMID: 7410019

$4 \mathrm{Yu}$ RJ and Van Scott EJ: Alpha-hydroxyacids and carboxylic acids. J Cosmet Dermatol 3(2): 76-87, 2004. PMID: 17147560., DOI: $10.1111 / \mathrm{j} .1473-2130.2004 .00059 . x$

5 Murad H, Shamban AT and Premo PS: The use of glycolic acid as a peeling agent. Dermatol Clin 13(2): 285-307, 1995. PMID: 7600706

6 National Industrial Chemicals Notification and Assessment Scheme (NICNAS): Glycolic acid, priority existing chemical assessment report no. 12 (2000). Available at https://www.nicnas.gov.au/ chemical-information/factsheets/chemical-name/glycolic-acid. Last accessed on 31 May 2019.

7 International Agency for Research on Cancer (IARC): List of classifications, volumes 1-123. (2018). Available at https:// monographs.iarc .fr/list-of-classifications-volumes/. Last accessed on 31 May 2019.

8 Chow FC, Dysart MI, Hamar DW and Udall RH: Control of oxalate urolithiasis by dl-alanine. Invest Urol 13(2): 113-116, 1975. PMID: 1184333 
9 Silbergeld S and Carter HE: Toxicity of glycolic acid in male and female rats. Arch Biochem Biophys 84: 183-187, 1959. PMID: 14446647

10 Andersen F, ed: Final report on the safety assessment of glycolic acid, ammonium, calcium, potassium, and sodium glycolates, methyl, ethyl, propyl, and butyl glycolates, and lactic acid, ammonium, calcium, potassium, sodium, and tealactates, methyl, ethyl, isopropyl, and butyl lactates, and lauryl, myristyl, and cetyl lactates. International Journal of Toxicology 17(1_suppl): 1-241, 1998. DOI: 10.1177/ 109158189801700101

11 Jacobsen D, Ovrebo S, Ostborg J and Sejersted OM: Glycolate causes the acidosis in ethylene glycol poisoning and is effectively removed by hemodialysis. Acta Med Scand 216(4): 409-416, 1984. PMID: 6516909

12 Agency for Toxic Substances and Disease Registry (ATSDR): Toxicological profile for ethylene glycol (2010). Available at https://www.atsdr.cdc.gov/toxprofiles/tp96.pdf. Last accessed on 31 May 2019.

13 DePass LR, Garman RH, Woodside MD, Giddens WE, Maronpot RR and Weil CS: Chronic toxicity and oncogenicity studies of ethylene glycol in rats and mice. Fundam Appl Toxicol 7(4): 547-565, 1986. PMID: 3803750

14 Melnick RL: Toxicities of ethylene glycol and ethylene glycol monoethyl ether in fischer 344/n rats and b6c3f1 mice. Environ Health Perspect 57: 147-155, 1984. PMID: 6499799., DOI: 10.1289/ehp.8457147

15 Blakeley KR, Rinner SE and Knochel JP: Survival of ethylene glycol poisoning with profound acidemia. N Engl J Med 328(7): 515-516, 1993. PMID: 8421485., DOI: 10.1056/NEJM 199302183280717

16 Cruzan G, Corley RA, Hard GC, Mertens JJ, McMartin KE, Snellings WM, Gingell R and Deyo JA: Subchronic toxicity of ethylene glycol in wistar and f-344 rats related to metabolism and clearance of metabolites. Toxicol Sci 81(2): 502-511, 2004. PMID: 15229367., DOI: 10.1093/toxsci/kfh206

17 Marr MC, Price CJ, Myers CB and Morrissey RE: Developmental stages of the cd (sprague-dawley) rat skeleton after maternal exposure to ethylene glycol. Teratology 46(2): 169-181, 1992. PMID: 1440420., DOI: 10.1002/tera.1420460210

18 Robinson M, Pond CL, Laurie RD, Bercz JP, Henningsen G and Condie LW: Subacute and subchronic toxicity of ethylene glycol administered in drinking water to sprague-dawley rats. Drug Chem Toxicol 13(1): 43-70, 1990. PMID: 2379473., DOI: $10.3109 / 01480549009011069$

19 Schladt L, Ivens I, Karbe E, Ruhl-Fehlert C and Bomhard E: Subacute oral toxicity of tetraethylene glycol and ethylene glycol administered to wistar rats. Exp Toxicol Pathol 50(3): 257-265, 1998. PMID: 9681658., DOI: 10.1016/S09402993(98)80096-1

20 Poore RE, Hurst CH, Assimos DG and Holmes RP: Pathways of hepatic oxalate synthesis and their regulation. Am J Physiol 272(1 Pt 1): C289-294, 1997. PMID: 9038835., DOI: 10.1152/ ajpcell.1997.272.1.C289

21 Richardson KE: The effect of partial hepatectomy on the toxicity of ethylene glycol, glycolic acid, glyoxylic acid and glycine. Toxicol Appl Pharmacol 24(4): 530-538, 1973. PMID: 4713480

22 Slikker W Jr., Andersen ME, Bogdanffy MS, Bus JS, Cohen SD, Conolly RB, David RM, Doerrer NG, Dorman DC, Gaylor DW, Hattis D, Rogers JM, Setzer RW, Swenberg JA and Wallace K:
Dose-dependent transitions in mechanisms of toxicity: Case studies. Toxicol Appl Pharmacol 201(3): 226-294, 2004. PMID: 15582646., DOI: 10.1016/j.taap.2004.06.027

23 Yanagawa M, Maeda-Nakai E, Yamakawa K, Yamamoto I, Kawamura J, Tada S and Ichiyama A: The formation of oxalate from glycolate in rat and human liver. Biochim Biophys Acta 1036(1): 24-33, 1990. PMID: 2223823., DOI: 10.1016/03044165(90)90209-f

24 Carstens J, Csanady GA, Faller TH and Filser JG: Human inhalation exposure to ethylene glycol. Arch Toxicol 77(8): 425432, 2003. PMID: 12856104., DOI: 10.1007/s00204-003-0468-5

25 Frantz SW, Beskitt JL, Grosse CM, Tallant MJ, Dietz FK and Ballantyne B: Pharmacokinetics of ethylene glycol. Ii. Tissue distribution, dose-dependent elimination, and identification of urinary metabolites following single intravenous, peroral or percutaneous doses in female sprague-dawley rats and cd-1 mice. Xenobiotica 26(11): 1195-1220, 1996. PMID: 8948094., DOI: $10.3109 / 00498259609050263$

26 Marshall TC: Dose-dependent disposition of ethylene glycol in the rat after intravenous administration. J Toxicol Environ Health 10(3): 397-409, 1982. PMID: 7175970., DOI: 10.1080/152 87398209530262

27 Jacobsen D, Hewlett TP, Webb R, Brown ST, Ordinario AT and McMartin KE: Ethylene glycol intoxication: Evaluation of kinetics and crystalluria. Am J Med 84(1): 145-152, 1988. PMID: 3337119., DOI: 10.1016/0002-9343(88)90024-1

28 Household Products Database: Glycolic acid (2019). Available at https://householdproducts.nlm.nih.gov/cgi-bin/household/ brands?tbl=chem\&id=12\&query $=$ glycolic+acid \&searchas=TblChe micals. Last accessed on 31 May 2019.

29 Shim I, Seo GB, Oh E, Lee M, Kwon JT, Sul D, Lee BW, Yoon BI, Kim P, Choi K and Kim HM: Inhalation exposure to chloramine $t$ induces DNA damage and inflammation in lung of sprague-dawley rats. J Toxicol Sci 38(6): 937-946, 2013. PMID: 24213014

30 Kennedy G and Burgess B: Inhalation toxicology of glycolic acid. Inhalation toxicology 9(5): 435-447, 1997. DOI: 10.1080/089583797198114

31 Danish Environmental Protection Agency (DEPA): Guidance for risk assessment of chemicals in consumer articles and products. Survey of chemical substances in consumer products no. 125 (2014). Available at https://www2.mst.dk/Udgiv/ publications/ 2014/03/978-87-93178-21-2.pdf. Last accessed on 31 May 2019.

32 European Chemicals Agency (ECHA): Guidance on information requirements and chemical safety assessment. Chapter r.7a: Endpoint specific guidance. Version 6.0. (2016). Available at https://echa.europa.eu/documents/10162/13632/information_requ irements_r7a_en.pdf. Last accessed on 31 May 2019.

33 Scientific Committee on Consumer Safety (SCCS): The sccs notes of guidance for the testing of cosmetic ingredients and their safety evaluation 9th revision. (2015). Available at https://ec.europa.eu/health/sites/health/files/scientific_committee s/consumer_safety/docs/sccs_o_224.pdf. Last accessed on 31 May 2019.

34 Yoo J, Lim YM, Kim H, Kim EJ, Lee DH, Lee B, Kim P, Yu SD, Kim HM, Yoon BI and Shim I: Potentiation of sodium metabisulfite toxicity by propylene glycol in both in vitro and in vivo systems. Front Pharmacol 9: 161, 2018. PMID: 29541028., DOI: $10.3389 /$ fphar.2018.00161 
35 Organization for Economic Co-operation and Development (OECD): Test no. 403: Acute inhalation toxicity. (2009). Available at https://www.oecd.org/env/test-no-403-acute-inhalation-toxicity9789264070608-en.htm. Last accessed on 31 May 2019.

36 Renne R, Brix A, Harkema J, Herbert R, Kittel B, Lewis D, March T, Nagano K, Pino M, Rittinghausen S, Rosenbruch M, Tellier $\mathrm{P}$ and Wohrmann T: Proliferative and nonproliferative lesions of the rat and mouse respiratory tract. Toxicol Pathol 37(7 Suppl): 5S-73S, 2009. PMID: 20032296., DOI: 10.1177/ 0192623309353423

37 Nazaroff WW and Weschler CJ: Cleaning products and air fresheners: Exposure to primary and secondary air pollutants. Atmospheric Environment 38(18): 2841-2865, 2004. DOI: 10.1016/j.atmosenv.2004.02.040

38 Nazarenko Y, Lioy PJ and Mainelis G: Quantitative assessment of inhalation exposure and deposited dose of aerosol from nanotechnology-based consumer sprays. Environ Sci Nano 1(2): 161-171, 2014. PMID: 25621175., DOI: 10.1039/C3EN00053B

39 Steiner M, Scaife A, Semple S, Hulks G and Ayres JG: Sodium metabisulphite induced airways disease in the fishing and fishprocessing industry. Occup Med (Lond) 58(8): 545-550, 2008. PMID: 18832347., DOI: 10.1093/occmed/kqn130

40 Folkesson HG, Matthay MA, Hebert CA and Broaddus VC: Acid aspiration-induced lung injury in rabbits is mediated by interleukin-8-dependent mechanisms. J Clin Invest 96(1): 107116, 1995. PMID: 7615779., DOI: 10.1172/JCI118009

41 Koenig JQ, Covert DS and Pierson WE: Effects of inhalation of acidic compounds on pulmonary function in allergic adolescent subjects. Environ Health Perspect 79: 173-178, 1989. PMID: 2539990., DOI: 10.1289/ehp.8979173

42 Hall JA, Yerramilli M, Obare E, Li J, Yerramilli M and Jewell DE: Serum concentrations of symmetric dimethylarginine and creatinine in cats with kidney stones. PLoS One 12(4): e0174854, 2017. PMID: 28384169., DOI: 10.1371/journal. pone.0174854

43 Fischer $\mathrm{H}$ and Widdicombe JH: Mechanisms of acid and base secretion by the airway epithelium. J Membr Biol 211(3): 139150, 2006. PMID: 17091214., DOI: 10.1007/s00232-006-0861-0

44 Ricciardolo FL, Gaston B and Hunt J: Acid stress in the pathology of asthma. J Allergy Clin Immunol 113(4): 610-619, 2004. PMID: 15100663., DOI: 10.1016/j.jaci.2003.12.034

45 Schlesinger RB: Effects of inhaled acids on respiratory tract defense mechanisms. Environ Health Perspect 63: 25-38, 1985. PMID: 3908089., DOI: 10.1289/ehp.856325
46 Daoui S, Cognon C, Naline E, Emonds-Alt X and Advenier C: Involvement of tachykinin nk3 receptors in citric acid-induced cough and bronchial responses in guinea pigs. Am J Respir Crit Care Med 158(1): 42-48, 1998. PMID: 9655705., DOI: 10.1164/ajrccm.158.1.9705052

47 Forsberg K, Karlsson JA, Theodorsson E, Lundberg JM and Persson CG: Cough and bronchoconstriction mediated by capsaicin-sensitive sensory neurons in the guinea-pig. Pulm Pharmacol 1(1): 33-39, 1988. PMID: 2980286

48 Girard V, Yavo JC, Emonds-Alt X and Advenier C: The tachykinin nk2 receptor antagonist sr 48968 inhibits citric acidinduced airway hyperresponsiveness in guinea pigs. Am J Respir Crit Care Med 153(5): 1496-1502, 1996. PMID: 8630592., DOI: 10.1164/ajrccm.153.5.8630592

49 Kopferschmitt-Kubler MC, Blaumeiser-Kapps M, Millet M, Wortham H, Mirabel P, Nobelis P and Pauli G: [study by questionnaire of the influence of weather conditions, particularly fog, on the symptomatology of asthmatic subjects]. Rev Mal Respir 13(4): 421-427, 1996. PMID: 8878363

50 Neas LM, Dockery DW, Koutrakis P, Tollerud DJ and Speizer FE: The association of ambient air pollution with twice daily peak expiratory flow rate measurements in children. Am J Epidemiol 141(2): 111-122, 1995. PMID: 7817967., DOI: 10.1093/oxfordjournals.aje.a117399

51 Kim E, Kwon J-T, Lee D-H, Park S-Y, Kim H-M, Kim P and Choi K: Ethylene glycol potentiated didecyldimethylammonium chloride toxicity in human bronchial epithelial cells. Molecular \& Cellular Toxicology 11(2): 161-166, 2015. DOI: $10.1007 / \mathrm{s} 132$ 73-015-0014-6

52 Kwon do Y, Kim HM, Kim E, Lim YM, Kim P, Choi K and Kwon JT: Acute pulmonary toxicity and inflammation induced by combined exposure to didecyldimethylammonium chloride and ethylene glycol in rats. J Toxicol Sci 41(1): 17-24, 2016. PMID: 26763389., DOI: 10.2131/jts.41.17
Received June 3, 2019

Revised July 1, 2019

Accepted July 3, 2019 